\title{
Direct effect of prolactin, induced by TRH injection, on ovarian oestradiol secretion in the ewe
}

\author{
A. S. McNeilly and D. T. Baird \\ $M R C$ Reproductive Biology Unit and Department of Obstetrics \& Gynaecology, \\ University of Edinburgh, Centre for Reproductive Biology, 37 Chalmers Street, \\ Edinburgh EH3 9EW, U.K.
}

\begin{abstract}
Summary. The effect of sustained high plasma levels of prolactin, induced by repeated $2-\mathrm{h}$ i.v. injections of thyrotrophin-releasing hormone (TRH;20 $\mu \mathrm{g}$ ), on ovarian oestradiol secretion and plasma levels of LH and FSH was investigated during the preovulatory period in the ewe. Plasma levels of progesterone declined at the same rate after prostaglandin-induced luteal regression in control and TRH-treated ewes. However, TRH treatment resulted in a significant increase in plasma levels of $\mathrm{LH}$ and FSH compared to controls from $12 \mathrm{~h}$ after luteal regression until 5 to $6 \mathrm{~h}$ before the start of the preovulatory surge of $\mathrm{LH}$. In spite of this, and a similar increase in pulse frequency of LH in control and TRH-treated ewes, ovarian oestradiol secretion was significantly suppressed in TRH-treated ewes compared to that in control ewes. The preovulatory surge of $\mathrm{LH}$ and FSH, the second FSH peak and subsequent luteal function in terms of plasma levels of progesterone were not significantly different between control and TRH-treated ewes.

These results show that TRH treatment, presumably by maintaining elevated plasma levels of prolactin, results in suppression of oestradiol secretion by a direct effect on the ovary in the ewe.
\end{abstract}

\section{Introduction}

The role of prolactin in the control of ovarian follicle growth and development in the sheep remains unknown (see McNeilly, Glasier, Jonassen \& Howie, 1982b). During the oestrous cycle plasma levels of prolactin show no significant trend until an increase coincident with oestrus and ovulation. This rise is due to both a stimulatory effect of increasing plasma levels of oestradiol in association with the first stages of follicle maturation and also a decrease in hypothalamic inhibition of prolactin secretion apparently necessary to allow the increase in luteinizing hormone releasing hormone ( $\mathrm{LH}-\mathrm{RH})$ release associated with the preovulatory surge of luteinizing hormone (LH) (see McNeilly, 1980; Baird \& McNeilly, 1981). During seasonal anoestrus plasma concentrations of prolactin are elevated (Walton, McNeilly, McNeilly \& Cunningham, 1977). It has been suggested that this increase in prolactin may play a role in the suppression of follicle growth associated with decreased gonadotrophin secretion in anoestrus (Walton et al., 1977; McNeilly et al., 1982b). Some support for this hypothesis is provided by the fact that the progesterone concentration is lower during the first 15 days of pregnancy of ewes mated in March, at a time of increased prolactin levels, than in ewes mated in December (Rhind, Chesworth \& Robinson, 1978).

To investigate the possible effect of high levels of prolactin in follicular steroidogenesis we have measured the changes in plasma levels of oestradiol and progesterone, $\mathrm{LH}$ and follicle-stimulating 
hormone (FSH) during the preovulatory period in ewes in which hyperprolactinaemia was induced by repeated injections of thyrotrophin-releasing hormone (TRH).

\section{Materials and Methods}

\section{Animals}

Six Tasmanian Merino $(\mathbf{M})$ and two Finnish-Landrace $\times$ Merino $(F \times M)$ ewes with ovarian transplants (Goding, McCracken \& Baird, 1967) and two Finnish Landrace $\times$ Merino ewes with uterovarian transplants (Harrison, Heap \& Linzell, 1968) were studied during the middle of the breeding season (January). Ewes were housed under natural lighting conditions in a covered pen at Dryden Field Station (Animal Breeding Research Organisation) Roslin, Midlothian, Scotland. The left ovary alone, or together with the oviduct, horn, and body of the uterus and cervix had been autotransplanted to the neck at least 2 years previously (Baird, Land, Scaramuzzi \& Wheeler, 1976). Because of the absence of cyclic ovarian function in the ewes with ovarian transplants, premature luteal regression was induced in all animals by i.m. injection $(100 \mu \mathrm{g})$ of cloprostenol, a potent analogue of prostaglandin F-2 $\alpha$ (Estrumate: ICI, Cheshire, U.K.). Luteal regression and oestrus occurred within 72 h of this treatment (Baird \& Scaramuzzi, 1975; Baird, Swanston \& McNeilly, 1981).

\section{Experimental design}

On Day 9 of the oestrous cycle after cloprostenol injection both jugular veins in all 10 ewes were cannulated as described previously (Collett, Land \& Baird, 1973; McNeilly, O'Connell \& Baird, 1982a). On the side of the utero-ovarian or ovarian anastomosis, a Silastic cannula (i.d. $2 \cdot 0 \mathrm{~mm}$; o.d. $3.2 \mathrm{~mm}$; Dow-Corning Corp., Midland, Michigan, U.S.A.) was advanced so that the tip lay near the site of the anastomosis of the utero-ovarian or ovarian and jugular vein. Animals were then kept in metabolism crates in a heated room (about $15^{\circ} \mathrm{C}$ ) until the end of the experiment.

On the morning of Day 10,5-ml samples of jugular venous blood were collected every hour for 6 $\mathrm{h}$ before to $60 \mathrm{~h}$ after a second i.m. injection of $100 \mu \mathrm{g}$ cloprostenol. From $60 \mathrm{~h}$ to $90 \mathrm{~h}$ samples were collected every $2 \mathrm{~h}$. Samples $(10 \mathrm{ml})$ of ovarian venous blood were collected at the same times. Samples of both jugular and ovarian venous blood were collected at 10 -min intervals for two periods of $4 \mathrm{~h}$ during the luteal phase $(-4$ to $0 \mathrm{~h}$ ) and follicular phase ( 24 to $28 \mathrm{~h}$ after cloprostenol injection). During these periods of frequent bleeding timed samples of ovarian blood were collected every hour and the plasma flow was then calculated from the haematocrit reading to allow subsequent calculation of the steroid secretion rate (Baird et al., 1981). Plasma was separated by centrifugation and stored at $-20^{\circ} \mathrm{C}$ until analysis.

From $36 \mathrm{~h}$ after injection of cloprostenol the ewes were tested for response to a male every $4 \mathrm{~h}$ to detect oestrus and continued until two successive tests were negative. The ewes were removed from the metabolism crates and observed in a pen with a vasectomized ram for $5 \mathrm{~min}$.

Five of the 10 ewes ( $3 \mathrm{M}$ and $1 \mathrm{~F} \times \mathrm{M}$ ovarian, $1 \mathrm{~F} \times \mathrm{M}$ utero-ovarian transplants) chosen at random were injected i.v. with $20 \mu \mathrm{g}$ TRH (Hoechst, Frankfurt, West Germany) every $2 \mathrm{~h}$ after cloprostenol injection for $60 \mathrm{~h}$. This dose of TRH has been shown to maintain hyperprolactinaemia in ewes (Kann \& Denamur, 1974).

\section{Hormone assays}

Prolactin, LH and FSH were measured in duplicate in specific double-antibody radioimmunoassays exactly as described in detail previously (McNeilly \& Andrews, 1974; McNeilly, McNeilly, Walton \& Cunningham, 1976; Martensz, Baird, Scaramuzzi \& Van Look, 1976). The sensitivities of the assays were $0.5 \mathrm{ng}$ prolactin (NIH-P-S6)/ml, $0.1 \mathrm{ng} \mathrm{LH}(\mathrm{NIH}-\mathrm{LH}-\mathrm{S} 14) / \mathrm{ml}$ and $8 \mathrm{ng}$ FSH 
(NIH-FSH-S10)/ml. The intra- and inter-assay variations as coefficients of variation $(\%)$ were $7 \cdot 7$ and $10.4 \%, 8.9$ and $11.3 \%$ and 8.4 and $12.1 \%$ for prolactin, $\mathrm{FSH}$ and $\mathrm{LH}$ respectively.

The oestradiol and progesterone concentrations in plasma were measured by specific radioimmunoassays as described previously (see Baird et al., 1981). Intra- and inter-assay coefficients of variation $(\%)$ were 6.0 and $9.5 \%$ and 9.8 and $13.0 \%$ for oestradiol and progesterone respectively.

\section{Statistical analysis}

The differences in hormone levels between groups were analysed in 6-h blocks by 2-way analysis of variance with repeated measures after $\log$ transformation. A rise in $\mathrm{LH}$ was considered to be a pulse if the value of two consecutive samples was greater than the mean of the two previous samples (basal value) and the value of at least one of the peak samples exceeded the mean basal value by more than twice the coefficient of variation of the assay (Backström, McNeilly, Leask \& Baird, 1982). Pulse frequency was analysed by $\chi^{2}$ test and differences between groups by unpaired Student's $t$ test.

\section{Results}

\section{Oestrous behaviour and ovulation}

All the ewes showed oestrus between 43 and $56 \mathrm{~h}$ after the injection of cloprostenol and TRH treatment did not affect this (mean \pm s.e.m. $47 \cdot 6 \pm 2.5 \mathrm{~h}$ for controls, $50 \pm 1 \cdot 3 \mathrm{~h}$ for TRH-treated ewes). While the duration of oestrus was similar in the $\mathrm{F} \times \mathrm{M}$ ewes in both groups (control: 38 and $40 \mathrm{~h}$; TRH-treated : 36 and $40 \mathrm{~h}$ ) it was considerably shorter in Merino ewes after TRH treatment (control : 20, 25 and $32 \mathrm{~h}$; TRH-treated : 12, 12 and $12 \mathrm{~h}$ ). All ewes appeared to ovulate, as judged by a single estimation of plasma progesterone concentration between Days 9 and 11 after oestrus and there was no significant difference in the progesterone values between control $(4.9 \pm 0.4 \mathrm{ng} / \mathrm{ml})$ and TRH-treated $(4.7 \pm 0.5 \mathrm{ng} / \mathrm{ml})$ animals.

\section{Plasma levels of prolactin, gonadotrophins and steroids}

For presentation and analysis of the changes in plasma levels of these hormones results have been centred around both the injection of cloprostenol and the peak plasma level of $\mathrm{LH}$ at the preovulatory surge.

Prolactin. The injection of $20 \mu \mathrm{g}$ TRH at the time of cloprostenol injection caused an immediate highly significant $(P<0.001)$ increase in plasma levels of prolactin compared to those in control animals (Text-fig. 1). The repeated TRH injections resulted in a sustained (2- to 10-fold) increase throughout the treatment period, with the prolactin increasing to a similar extent after each TRH injection (Text-fig. 2). In control animals prolactin levels increased at the time of the LH surge and thereafter decreased to values similar to those before cloprostenol injection.

Progesterone. Plasma levels of progesterone declined rapidly within $6 \mathrm{~h}$ of the injection of cloprostenol and plasma levels fell to $<1 \mathrm{ng} / \mathrm{ml}$ within $24 \mathrm{~h}$ in all animals. There was no significant difference in response between control and TRH-treated ewes (Text-fig. 3).

$L H$. By $6 \mathrm{~h}$ after cloprostenol injection plasma levels of LH increased significantly $(P<0.01)$ in the control $(0.7 \pm 0.4$ to $1.6 \pm 0.4 \mathrm{ng} / \mathrm{ml})$ and TRH-treated $(1.4 \pm 0.4$ to $3.2 \pm 1.2 \mathrm{ng} / \mathrm{ml})$ animals. While LH concentrations before cloprostenol injection were not significantly different, the values in TRH-treated ewes from 6 to $24 \mathrm{~h}$ after injection were greater than in controls $(P<0.01$, Text-fig. 1a). Plasma levels of LH remained significantly $(P<0 \cdot 01)$ higher in TRH-treated than control ewes between 36 and $6 \mathrm{~h}$ before the LH peak (Text-fig. la). The peak preovulatory surge occurred at similar times after cloprostenol injection in both groups (control : $61 \pm 4 \mathrm{~h}$, range 52-68 
$(\mid u / 6 u)$ Hา

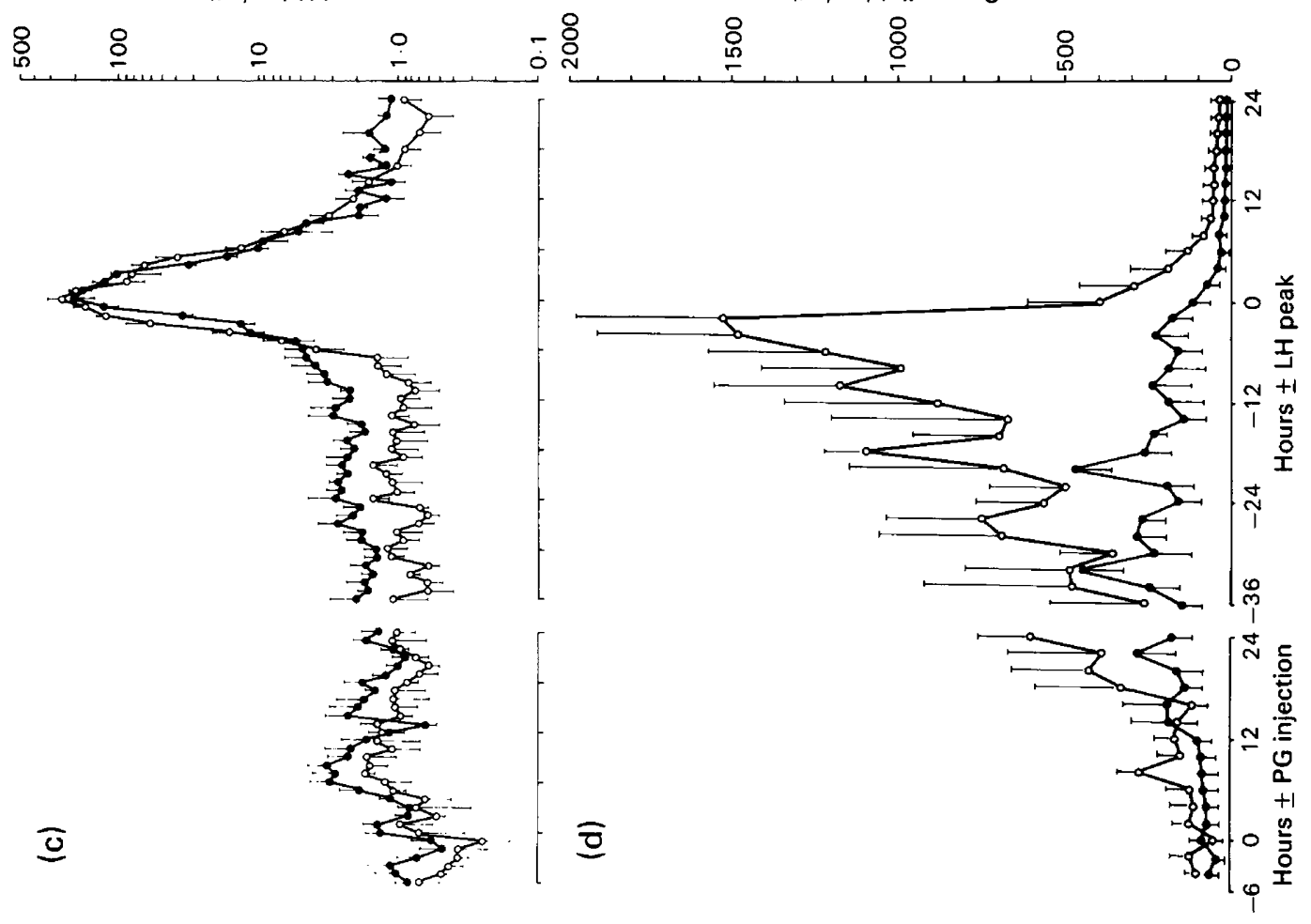

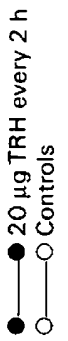

즌
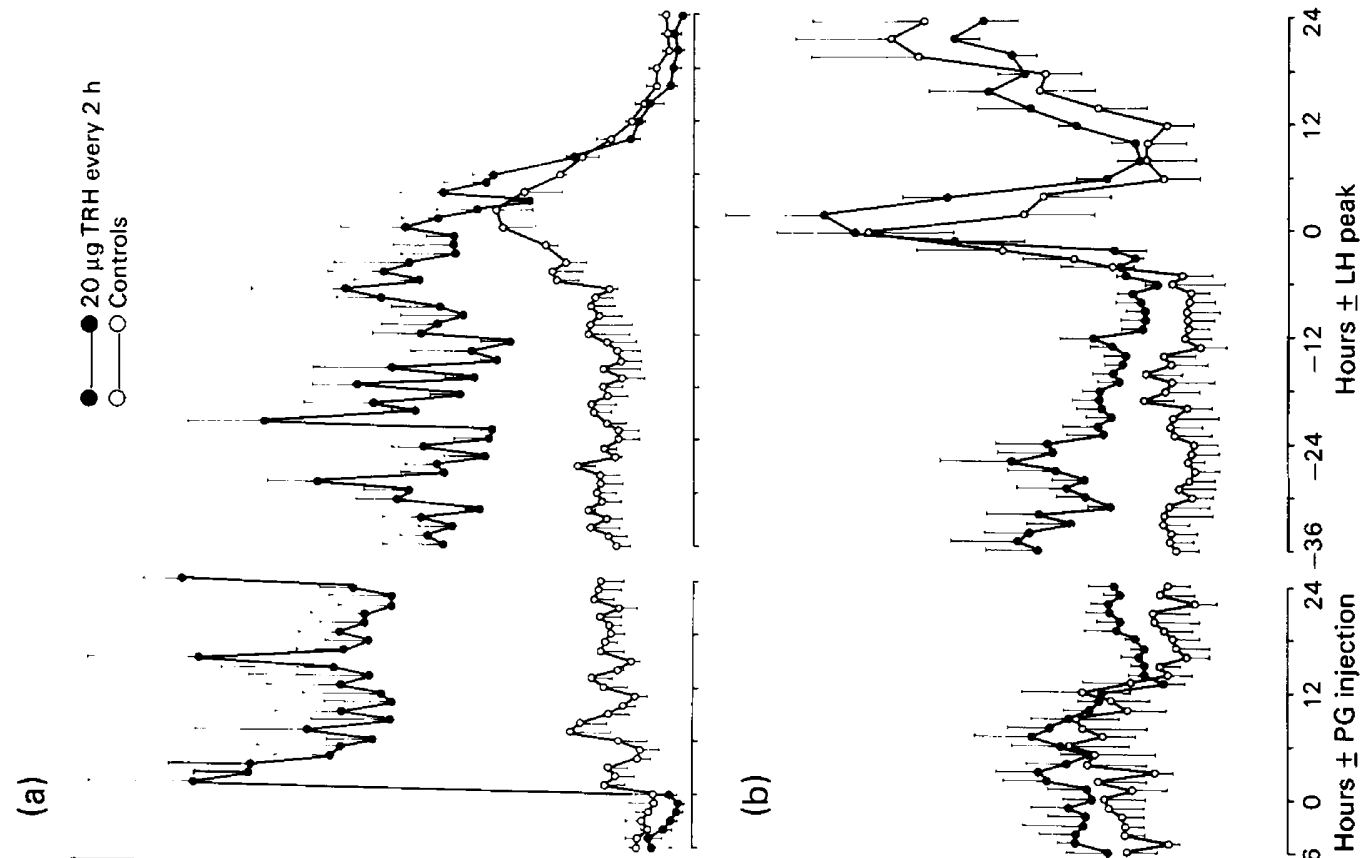

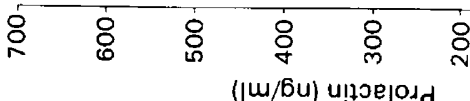

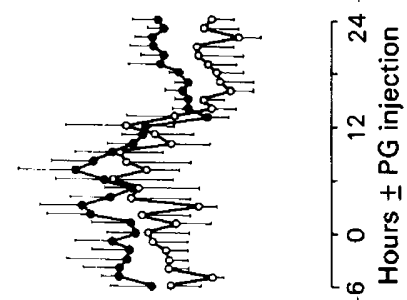

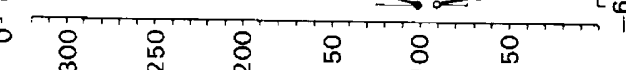

( $\mathrm{w} / \mathrm{bu}) \hat{\mathrm{HSJ}}$ 


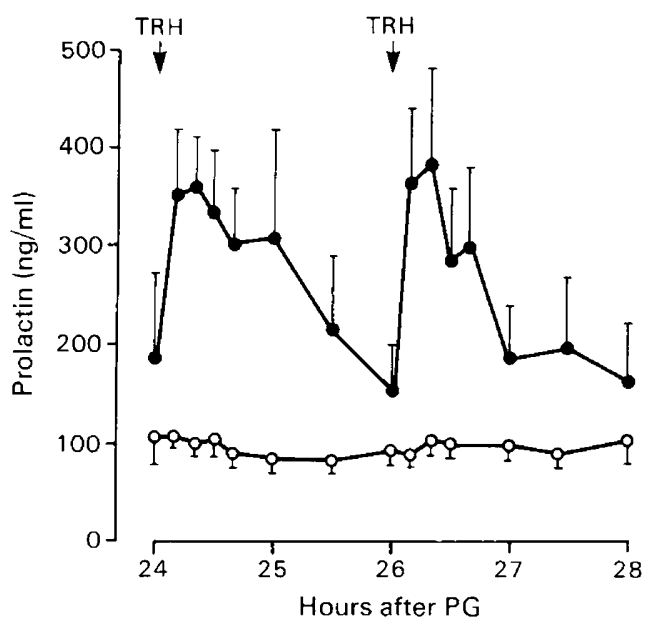

Text-fig. 2. Concentration of prolactin in jugular venous plasma of ewes 24-28 h after induction of luteal regression by injection of $100 \mu \mathrm{g}$ cloprostenol on Day 10 of the cycle and treated with $20 \mu \mathrm{g}$ TRH every $2-\mathrm{h}(-\mathrm{O})$. O, Controls. Each point represents the mean \pm s.e.m. of 5 observations.

h; TRH-treated : $55 \pm 4$ h, range $41-65$ h). Peak levels (controls : $258 \pm 79$; TRH-treated : $206 \pm 49$ $\mathrm{ng} / \mathrm{ml}$ ) and cumulative release of $\mathrm{LH}$ during the surge (controls: $551 \pm 62$; TRH-treated : $462 \pm 83$ $\mathrm{ng} / \mathrm{ml},-6$ to $+6 \mathrm{~h}$ around peak) were not significantly different.

$F S H$. After the injection of cloprostenol, plasma levels of FSH increased slightly but then declined in the control and TRH-treated ewes (Text-fig. 1b). By $24 \mathrm{~h}$ after cloprostenol, levels were significantly $(P<0.05$; paired $t$ test) lower than preinjection levels in control ewes $(104 \pm 2.3$ and $68 \pm 13 \mathrm{ng} / \mathrm{ml})$ but not in TRH-treated ewes $(110 \pm 17$ and $98 \pm 15 \mathrm{ng} / \mathrm{ml})$.

Between 36 and $6 \mathrm{~h}$ before the LH surge, FSH levels remained suppressed in control ewes. However, during this time the FSH values in TRH-treated ewes were significantly $(P<0.001)$ higher than controls although a significant $(P<0.05)$ decline did occur before the start of the LH surge.

Coincidental to the LH surge, there was a 4-fold increase in FSH in both groups, giving similar peak levels (control : $248 \pm 42 \mathrm{ng} / \mathrm{ml}$; TRH-treated: $306 \pm 37 \mathrm{ng} / \mathrm{ml}$; Text-fig. 1c). FSH levels then returned to basal values (control: $56 \pm 18 \mathrm{ng} / \mathrm{ml}$; TRH-treated: $82 \pm 17 \mathrm{ng} / \mathrm{ml}$ ) between 8 and 10-h and subsequently rose again to peak values (control: $218 \pm 70 \mathrm{ng} / \mathrm{ml}$; TRH-treated: $237 \pm 31 \mathrm{ng}$ / $\mathrm{ml}) 16$ to $33 \mathrm{~h}$ after the $\mathrm{LH}$ peak. There was no significant difference between control and TRHtreated ewes in these changes in FSH around the LH surge.

Oestradiol. Between 6 and $12 \mathrm{~h}$ after cloprostenol injection there was a rise in the secretion of oestradiol which was similar in control and TRH-treated ewes (Text-fig. 1c). This increase continued until levels reached a peak between 44 and $66 \mathrm{~h}$ after cloprostenol injection. However, oestradiol values were significantly $(P<0.05)$ lower between -24 and $+12 \mathrm{~h}$ around the LH surge

Text-fig. 1. Concentration of FSH, LH and prolactin in jugular venous plasma and oestradiol in ovarian venous plasma of ewes after injection of $100 \mu \mathrm{g}$ cloprostenol on Day 10 of the cycle and treated with $20 \mu \mathrm{g}$ TRH every $2 \mathrm{~h}$. The results have been grouped around the time of the cloprostenol injection (PG) or the LH peak. Each point represents the mean \pm s.e.m. of 5 observations (4 for oestradiol). 


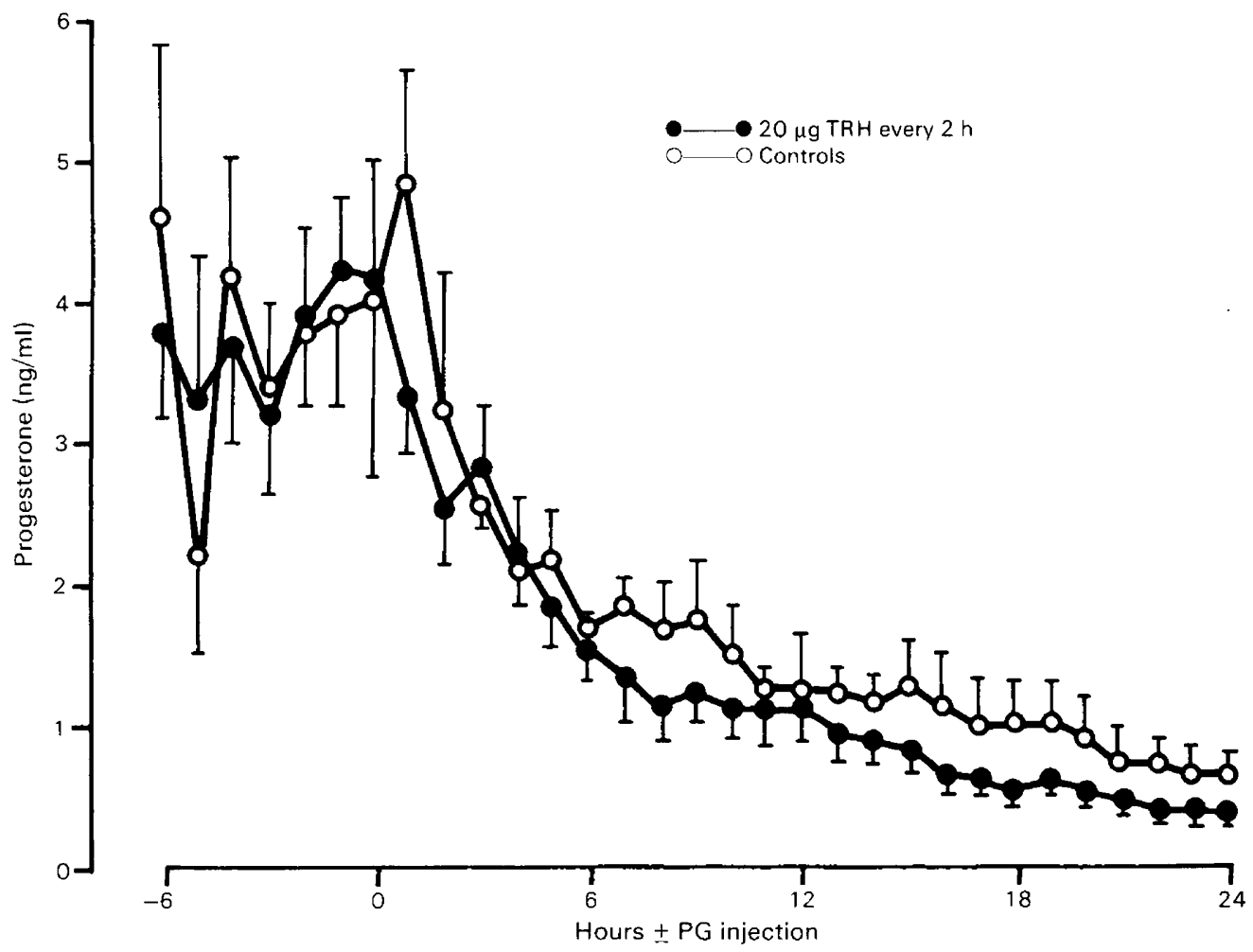

Text-fig. 3. The concentration of progesterone in jugular venous plasma of ewes after injection of $100 \mu \mathrm{g}$ cloprostenol on Day 10 of the cycle. Each point represents the mean \pm s.e.m. of 5 observations.

in TRH-treated than control ewes (Text-fig. 1c). Peak values of oestradiol occurred significantly ( $P$ $<0.001$ ) earlier relative to the LH surge in TRH-treated than control ewes (TRH-treated: -32 , $-20,-20$ and $-12 \mathrm{~h}$; control: $-18,-10,-8$ and $-4 \mathrm{~h}$ ). By $12 \mathrm{~h}$ after the LH peak in both groups, oestradiol declined to values lower than at any stage of the preovulatory phase (Text-fig. 1c).

\section{Pulsatile release of $L H$ and oestradiol}

The change in pulsatile secretion of LH and oestradiol and the associated changes in FSH during the luteal phase and 24-28 h after cloprostenol injection were assessed from results of 4-h periods of intensive bleeding at each stage. The number of LH pulses in the $20 \mathrm{~h}$ of observation rose from 8 in the luteal phase to 18 and 20 in the control and TRH-treated ewes. Pulse amplitude did not alter during this time (luteal phase : $0.8 \pm 0.3$; follicular phase, control: $0.9 \pm 0.3 \mathrm{ng} / \mathrm{ml}$; TRHtreated $0.9 \pm 0.2 \mathrm{ng} / \mathrm{ml})$. However, basal levels of $\mathrm{LH}$ were significantly $(P<0.05)$ higher in the TRH-treated ewes (Text-fig. 4). All LH pulses were accompanied by an increase in oestradiol secretion. However, while in control animals there was a marked increase in both basal and peak secretion of oestradiol in the follicular than in the luteal phase, this was drastically reduced in the TRH-treated ewes (Text-fig. 4). FSH levels in the control and TRH-treated ewes were significantly lower $(P<0.01)$ in the follicular than luteal phase, but those in the follicular phase were significantly $(P<0.001)$ lower in control than TRH-treated ewes. 


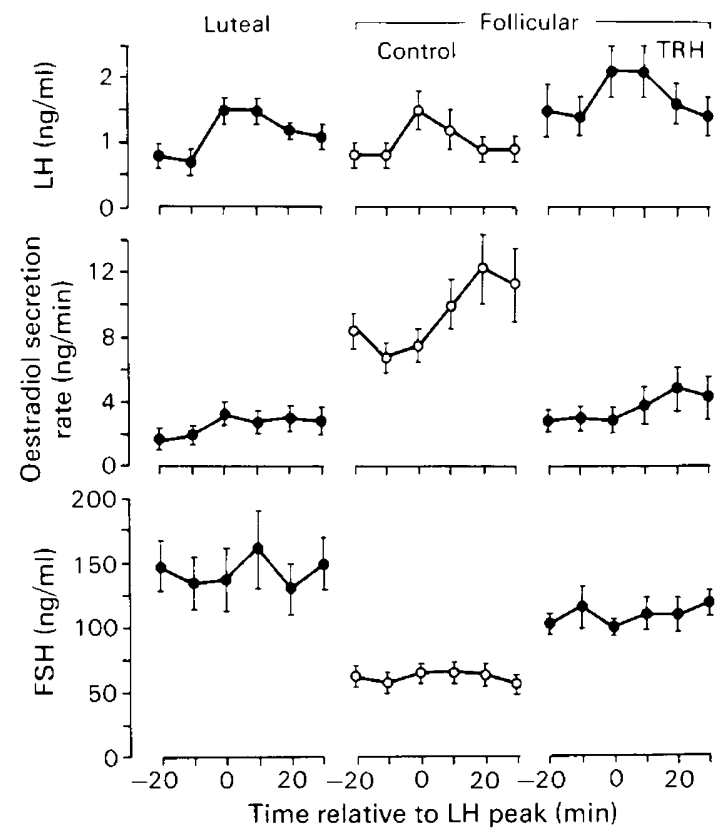

Text-fig. 4. Pulsatile secretion of LH, FSH and oestradiol in ewes on Day 10 (luteal phase) and 24-28 h after injection of cloprostenol (follicular phase). The results have been grouped round the LH peak. Each point represents the mean \pm s.e.m. of 5 observations.

\section{Discussion}

The present study demonstrated that a sustained increase in plasma levels of prolactin in the preovulatory phase of the oestrous cycle in the ewe is associated with a significant reduction in ovarian secretion of oestradiol. Since plasma levels of both LH and FSH were higher than in control ewes, the results imply that the high levels of prolactin reduced oestradiol secretion by a direct action at the ovarian level.

We have confirmed that repeated injections of TRH will maintain an increase in prolactin concentrations over control values (Kann, Martinet \& Schirar, 1977) and responsiveness is maintained through the 60 -h injection period. However, in spite of this increase in prolactin concentration, injection of prostaglandin resulted in a marked decline in plasma levels of progesterone and functional luteolysis at the same rate as in untreated ewes. This contrasts with results for the rat in which prolactin appears to protect the corpus luteum from prostaglandininduced luteolysis (Behrman, Grinwich, Hichens \& MacDonald, 1978). However, this difference may only be due to the use of a more active analogue of prostaglandin in the present experiment rather than the PGF- $2 \alpha$ used in the rat studies.

Throughout most of the preovulatory period, basal levels of LH were higher in TRH-treated than control ewes. It was also clear that the increase in pulse frequency of LH associated with this period was unaffected. Nevertheless, the greater increase in basal level of LH in the TRH-treated ewes only resulted in inducing oestradiol secretion at one third that of normal throughout the preovulatory phase. Indeed, since the peak values of oestradiol occurred significantly earlier in TRH-treated than control ewes it was also clear that the follicle(s) producing the oestradiol could not respond with the normal large increase in oestradiol secretion that occurs in response to the first increase in basal $\mathrm{LH}$ at the start of the preovulatory surge of LH (Baird et al., 1981). These results 
clearly imply a reduction in responsiveness of the ovary to $\mathrm{LH}$. The fact that plasma levels of FSH were also higher in TRH-treated than control ewes throughout the preovulatory phase was presumably a result of the reduction in negative feedback due to the reduced levels of oestradiol, and perhaps other ovarian factor(s) such as inhibin, during the preovulatory phase (see Baird \& McNeilly, 1981).

These results indicate that the reduction in secretion of oestradiol is not a consequence of failure of normal gonadotrophin secretion but imply a suppression of responsiveness to gonadotrophin stimulation at the ovarian level in the TRH ewes. Clearly, the raised plasma levels of prolactin could be responsible for this suppression.

Normal secretion of oestradiol requires both the stimulation by $\mathrm{LH}$ of androgen production, principally androstenedione and testosterone, from the theca and its conversion to oestradiol by an active aromatase system induced by FSH and possibly LH in the granulosa cell layer of the follicle (Moor, 1977; Armstrong, Weiss, Selstam \& Seamark, 1981; Baird \& McNeilly, 1981; McNatty, Gibb, Dobson, Thurley \& Findlay, 1981). Injection in vivo of large amounts of prolactin during prooestrus in the rat inhibits the production of oestrogen by follicles incubated in vitro although the site of this inhibition is not known (Uilenbroek, van der Schoot, den Besten \& Lankhorst, 1982). However, high levels of prolactin can block both the induction by FSH of aromatase in rat granulosa cells in vitro (Dorrington \& Gore-Langton, 1981) and LH-induced androgen production from ovarian thecal and interstitial cells in vitro (Magoffin \& Erickson, 1982). It is not clear from our present results which, if either, of these two possible points of steroid inhibition are responsible for the suppression of oestradiol secretion, although preliminary observations suggest that thecal androgen production may be reduced (McNeilly et al., 1982b). It is also possible that prolactin may interfere with the induction and maintenance of LH receptors on the theca and LH and FSH receptors on granulosa cells of the developing preovulatory follicle. These receptors appear and increase in number during the final stages of follicle maturation (Carson, Findlay, Burger \& Trounson, 1979; Webb \& England, 1982). However, this seems unlikely as most studies of the rat indicate that prolactin is part of the hormonal complex necessary for the induction and maintenance of LH receptors in the follicle and corpus luteum (Richards \& Williams, 1976; Holt, Richards, Midgley \& Reichert, 1976).

In spite of the reduced levels of oestradiol, the preovulatory surges of LH and FSH and the second peak of FSH occurred normally in the TRH-treated ewes. Clearly, therefore, sufficient oestradiol had been produced to elicit the normal positive feedback response. However, the duration of oestrus, another biological indicator of preovulatory oestrogen secretion, was substantially shorter in the TRH-treated than in the control Merino ewes. Such an effect was not seen in the Finn-Merino ewes, perhaps because of a different sensitivity to oestrogen (Land, Thompson \& Baird, 1972). Nevertheless, luteal function, in terms of plasma levels of progesterone, were similar in the control and TRH-treated ewes, suggesting that sufficient oestradiol was secreted in the preovulatory phase in TRH-treated ewes to allow apparently normal follicular maturation. However, such alterations in the steroid milieu of the follicle might affect the maturation of the oocyte. It has been suggested that the intrafollicular hormonal environment is important (McNatty et al., 1981) and a role for prolactin has been suggested in oocyte maturation (Baker \& Hunter, 1978; Nolin, 1980) and in the production by the follicle of oocyte maturation inhibitory factor (Channing \& Evans, 1982). High levels of prolactin have been implicated in reduced progesterone levels and fertility in sheep mated towards the end of the breeding season (Rhind et al., 1978).

The present study provides direct evidence that treatment of sheep with TRH results in a suppression of LH and FSH-induced follicular oestradiol secretion in the preovulatory phase by a direct action on the ovary. This action is presumed to be through the induction of sustained high levels of prolactin but repeated injections of TRH may also result in an increase in thyroidstimulating hormone (TSH) and the thyroid hormones triiodothyronine and thyroxine (Fraser \& McNeilly, 1982) and this alteration in thyroid status might also be implicated. 
We thank Professor W. R. Butt, Dr S. S. Lynch and the NIAMDD (Bethesda, Maryland, U.S.A.) for hormones and antiserum used in the radioimmunoassays; Miss B. Archibald, Mr I. A. Swanston and Mr D. Davidson for skilled technical assistance; the staff at Dryden Field Station; Mr T. McFetters and Mr E. Pinner for preparation of the figures; and Mrs S. McGonagle for typing the manuscript.

\section{References}

Armstrong, D.T., Weiss, T.J., Selstam, G. \& Seamark, R.F. (1981) Hormonal and cellular interactions in follicular steroid biosynthesis by the sheep ovary. $J$. Reprod Fert., Suppl. 30, 143-154.

Backström, C.T., McNeilly, A.S., Leask, R.M. \& Baird, D.T. (1982) Pulsatile secretion of LH, FSH, prolactin, oestradiol and progesterone during the human menstrual cycle. Clin. Endocr. 17, 29-42.

Baird, D.T. \& McNeilly, A.S. (1981) Gonadotrophic control of follicular development and secretion in the sheep oestrous cycle. J. Reprod. Fert., Suppl. 30, 119 133.

Baird, D.T. \& Scaramuzzi, R.J. (1975) Prostaglandin $\mathrm{F}_{2} \alpha$ and luteal regression in the ewe; comparison with 16aryloxy-prostaglandin (ICI 80,996). Annls Biol anim. Biochim. Biophys, 15, 161-174.

Baird, D.T., Land, R.B., Scaramuzzi, R.J. \& Wheeler, A.G. (1976) Functional assessment of autotransplanted uterus and ovary in the ewe. Proc. R. Soc. B 192, 463-474.

Baird, D.T., Swanston, I.A. \& McNeilly, A.S. (1981) Relationship between LH, FSH and prolactin concentration and the secretion of androgens and estrogens by the preovulatory follicle in the ewe. Biol. Reprod. 24, 1013-1025.

Baker, T.G. \& Hunter, R.H.F. (1978) Interrelationships between the oocyte and somatic cells within the Graafian follicle of mammals. Annls Biol anim. Biochim. Biophys. 18, 419-426.

Behrman, H.R., Grinwich, D.L., Hichens, M. \& MacDonald, G.J. (1978) Effect of hypophysectomy, prolactin, and prostaglandin $F_{2} \alpha$ on gonadotropin binding in vivo and in vitro in the corpus luteum. Endocrinology 103, 349-357.

Carson, R.S., Findlay, J.K., Burger, H.G. \& Trounson, A.O. (1979) Gonadotropin receptors of the ovine ovarian follicle during follicular growth and atresia. Biol. Reprod. 21, 75-87.

Channing, C.P. \& Evans, V.W. (1982) Stimulatory effect of ovine prolactin upon cultured porcine granulosa cell secretion of inhibitory activity of oocyte maturation. Endocrinology 111, 1746-1748.

Collett, R.A., Land, R.B. \& Baird, D.T. (1973) The pattern of progesterone secretion by the autotransplanted ovary of the ewe in response to luteinizing hormone. J. Endocr. 56, 403-411.

Dorrington, J. \& Gore-Langton, R.E. (1981) Prolactin inhibits oestrogen synthesis in the ovary. Nature, Lond. 290, 600-602.

Fraser, H.M. \& McNeilly, A.S. (1982) Effect of chronic immunoneutralization of thyrotropin releasing hormone on the hypothalamic-pituitary-thyroid axis, prolactin, and reproductive function in the ewe. Endocrinology 111, 1964-1973.
Goding, J.R., McCracken, J.A. \& Baird, D.T. (1967) The study of ovarian function in the ewe by means of a vascular autotransplantation technique. $J$. Endocr. 39, 37-62.

Harrison, F.A., Heap, R.B. \& Linzell, J.L. (1968) Ovarian function in the sheep after autotransplantation of the ovary and uterus to the neck. J. Endocr. 40, xiii, Abstr.

Holt, J.A., Richards, J.S., Midgley, A.R., Jr \& Reichert, L.E., Jr (1976) Effect of prolactin on LH receptor in rat luteal cells. Endocrinology 98, 1005-1013.

Kann, G. \& Denamur, R. (1974) Possible role of prolactin during the oestrous cycle and gestation in the ewe. $J$. Reprod. Fert. 39, 473-483.

Kann, G., Martinet, J. \& Schirar, A. (1977) Hypothalamic-pituitary control during lactation in the sheep. In Control of Ovulation, pp. 319-333. Eds D. B. Crighton, N. B. Haynes, G. R. Foxcroft \& G. E. Lamming. Butterworths, London.

Land, R.B., Thompson, R. \& Baird, D.T. (1972) Duration of oestrus in ovariectomized Finnish Landrace and Scottish Blackface ewes following progesterone and oestrogen treatment. J. Reprod. Fert. 30, 39-44.

Magoffin, D.A. \& Erickson, G.F. (1982) Prolactin inhibition of luteinizing hormone-stimulated androgen synthesis in ovarian interstitial cells in defined medium: mechanism of action. Endocrinology 111, 2001-2007.

Martensz, N.D., Baird, D.T., Scaramuzzi, R.J. \& Van Look, P.F.A. (1976) Androstenedione and the control of luteinizing hormone in the ewe during anoestrus. $J$. Endocr. 69, 227-237.

McNatty, K.P., Gibb, M., Dobson, C., Thurley, D.C. \& Findlay, J.K. (1981) Changes in the concentration of gonadotrophin and steroidal hormones in the antral fluid of ovarian follicles throughout the oestrous cycle of the sheep. Aust. J. biol. Sci. 34, 67-80.

McNeilly, A.S. (1980) Prolactin and the control of gonadotrophin secretion in the female. J. Reprod. Fert. 58, 537-549.

McNeilly, A.S. \& Andrews, P. (1974) Purification and characterization of caprine prolactin. J. Endocr. 60, $359-367$.

McNeilly, J.R., McNeilly, A.S., Walton, J.S. \& Cunningham, F.J. (1976) Development and application of a heterologous radioimmunoassay for ovine follicle stimulating hormone. J. Endocr. 70, 69-79.

McNeilly, A.S., O'Connell, M. \& Baird, D.T. (1982a) Induction of ovulation and normal luteal function by pulsed injections of luteinizing hormone in anestrous ewes. Endocrinology 110, 1292-1299.

McNeilly, A.S., Glasier, A., Jonassen, J. \& Howie, P.W. (1982b) Evidence for direct inhibition of ovarian function by prolactin. J. Reprod. Fert. 65, 559-569. 
Moor, R.M. (1977) Sites of steroid production in ovine Graafian follicles in culture. J. Endocr. 73, 143-150.

Nolin, J.M. (1980) Incorporation of endogenous prolactin by granulosa cells and dictyate oocytes in the postpartum rat : effects of estrogen. Biol. Reprod. 22, 417-422.

Rhind, S.M., Chesworth, J.M. \& Robinson, J.J. (1978) A seasonal difference in ovine peripheral plasma prolactin and progesterone concentrations in early pregnancy and the relationship between the two hormones. J. Reprod. Fert. 52, 79-81.

Richards, J.S. \& Williams, J.J. (1976) Luteal cell receptor content for prolactin (PRL) and luteinizing hormone (LH): regulation by LH and PRL. Endocrinology 99, 1571-1581.

Uilenbroek, J.Th.J., van der Schoot, P., den Besten, D. \&
Lankhorst, R.R. (1982) A possible direct effect of prolactin on follicular activity. Biol. Reprod. 27, 1119-1125.

Walton, J.S., McNeilly, J.R., McNeilly, A.S. \& Cunningham, F.J. (1977) Changes in concentrations of follicle-stimulating hormone, luteinizing hormone, prolactin and progesterone in the plasma of ewes during the transition from anoestrus to breeding activity. J. Endocr. 75, 127-136.

Webb, R. \& England, B.G. (1982) Relationship between LH receptor concentrations in thecal and granulosa cells and in vivo and in vitro steroid secretion by ovine follicles during the preovulatory period. $J$. Reprod. Fert. 66, 169-180.

Received 28 February 1983 